\title{
Sejarah Perkembangan Sistem Pendidikan Islam di Pesantren Ar-Raudlatul Hasanah Kota Medan
}

\author{
Muhammad Andre Syahbana Siregar \\ Guru Sejarah SMA Negeri 3 Medan \\ syahbanaandre@gmail.com
}

\begin{abstract}
This research aims to discuss about Islamic education, especially the pesantren institution which located in Medan. Pesantren Ar-Raudhlatul Hasanah is an object in this research by using the qualitative method and field research. About 34 years, this pesantren became an important part to developing Islamic education and furthermore to build the character Indonesian generations, especially in Medan. This pesantren also have santri (student) whose came from neighbors state, such as Malaysia and Thailand. As a modern education institution, this pesantren success to integrate between the Kuliiyatul Mu'allimin Al-Islamiyah as the curriculum which adopted from Modern Pesantren Gontor and the National Curriculum. So this pesantren have three roles: as the pesantren, the madrasah, and the school.
\end{abstract}

Keywords: Pesantren Ar-Raudlatul Hasanah, Islamic education system, character of the nation.

\begin{abstract}
Abstrak
Artikel ini bertujuan untuk membahas tentang perkembangan dunia pendidikan Islam, khususnya lembaga pendidikan pesantren yang berada di Kota Medan. Objek penelitian ini adalah Pesantren Ar-Raudlatul Hasanah. Metode penelitian yang digunakan adalah metode kualitatif dengan mengandalkan studi lapangan. Selama kurang lebih 34 tahun pesantren ini telah menjadi bagian penting dalam membangun dunia pendidikan Islam terutama membangun karakter generasi bangsa di Indonesia, khususnya di Kota Medan. Pesantren ini juga memiliki santri yang berasal dari negeri jiran, seperti dari Malaysia dan Thailand. Sebagai lembaga pendidikan pesantren modern, pesantren ini berhasil memadukan antara kurikulum Kuliiyatul Mu'allimin Al-Islamiyah yang diadopsi dari Pesantren Modern Gontor dan kurikulum nasional milik pemerintah sehingga memiliki tiga peran: sebagai pesantren, sebagai madrasah, dan sebagai sekolah.
\end{abstract}

Kata Kunci: Pesantren Ar-Raudlatul Hasanah, sistem pendidikan Islam, karakter bangsa.

\section{PENDAHULUAN}

Pendidikan merupakan pondasi awal untuk membangun bangsa, oleh sebab itu maka penting bagi kita untuk melihat sejauh mana kualitas pendidikan yang telah diselenggarakan untuk masyarakat. Penyelenggaraan pendidikan yang berkualitas diharapkan akan menghasilkan generasi yang bermutu, terutama generasi yang berkarakter baik, berakhlak, santun, serta memiliki kecerdasan intelektual yang baik. Tujuan pendidikan Islam adalah: mempersiapkan manusia untuk hidup dengan sempurna dan bahagia, mencintai tanah air, 
tegap jasmaninya, sempurna budi pekertinya, pola pikirnya teratur dengan rapi, perasaannya halus, profesional dalam bekerja dan manis tutur sapanya. ${ }^{1}$

Hal demikian merupakan cita-cita dari penyelenggaraan pendidikan dalam rangka memanusiakan manusia. Oleh karenanya, penyelenggaraan pendidikan di pesantren-pesantren di Indonesia telah menjadi bagian dari perjalanan panjang sejarah Pendidikan Islam di Indonesia. Dari pesantren pula lahir banyak sekali tokoh-tokoh intelektual nasional seperti Hasyim Asy'ari, Ahmad Dahlan, Zainal Mustafa dan lain-lain. Pada masa awal permulaan kemerdekaan pesantren menjadi sasaran penting bagi pemerintah untuk mengembangkan dunia pendidikan di Indonesia. Sistem pendidikan Islam yang ada dan telah berkembang pada masa pasca kemerdekaan sebagai salah satu bentuk dan usaha pelaksanaan syariat Islam mendapat kesempatan dan jaminan untuk tetap berlangsung dan berkembang, serta mendapat perhatian dan bantuan dari pemerintah. ${ }^{2}$ Adanya perhatian pemerintah yang menghadirkan undang-undang untuk mengatur pendidikan pada lembaga pendidikan keagamaan menjadikan pesantren memiliki peluang yang besar untuk mengembangkan pendidikan Islam di Indonesia.

\section{HASIL DAN PEMBAHASAN}

Pesantren memiliki berbagai macam definisi menurut para ahli. Asal etimologi dari pesantren adalah pesantrian yang berupa tempat santri. ${ }^{3 \text { " }}$ Hal ini diperkuat dengan definisi pesantren oleh Dhofier yang mengatakan bahwa "perkataan pesantren berasal dari kata santri, yang dengan awalan pe di depan dan akhiran an berarti tempat tinggal para santri." 4 Maka dapat diartikan bahwa pesantren merupakan tempat para santri untuk melaksanakan pendidikan dan lembaga itu dijadikan tempat tinggal bagi mereka (asrama). Secara terminologis pendidikan pesantren dilihat dari segi bentuk dan sistemnya berasal dari India. Sebelum proses penyebaran Islam di Indonesia, sistem tersebut telah digunakan secara umum untuk pendidikan dan pengajaran agama Hindu di Jawa. Istilah pesantren sendiri seperti halnya mengaji bukanlah berasal dari Arab, melainkan dari India, demikian juga istilah pondok, langgar di Jawa, surau di Minangkabau dan rangkang di Aceh bukanlah merupakan istilah Arab, tetapi dari istilah yang terdapat di India. ${ }^{5}$ Pendapat ini juga mendapat penguatan oleh Pola pendidikan mengenai pesantren oleh Bruinessen yang menjelaskan bahwa "pola khas pesantren sebagai lembaga pendidikan juga mencerminkan pengaruh asing, dan mungkin juga punya akar asing (meski bercampur dengan tradisi lokal yang lebih tua). Ia menyerupai madrasah India dan Timur

\footnotetext{
${ }^{1}$ Hasan, Basri. Kapita Selekta Pendidikan. Bandung: CV Pustaka Setia, 2012. h.17

2 Susanto. Pemikiran Pendidikan Islam. Jakarta: Amzah, 2010. h.18

3 Daulay, Putra Haidar. Sejarah Pertumbuhan dan Pembaharuan Pendidikan Islam Di Indonesia. Jakarta: Kencana Prana Media Group, 2009. h.61

4 Dhofier, Zamakhsyari. Tradisi Pesantren. Jakarta Barat: LP3ES, 2011. h.41

${ }^{5}$ Steenbrink, Karel A.Pesantren Madrasah Sekolah Pendidikan Islam Dalam Kurun Modern. Jakarta Barat: LP3ES, 1985. h.20
} 
Tengah." ${ }^{6}$ Dengan kata lain lembaga pendidikan ini memiliki pola kombinasi antara lembaga pendidikan daerah di luar Indonesia dengan tradisi yang sudah lama dimiliki orang Indonesia. Dengan demikian pesantren sebagai lembaga pendidikan Islam telah mengalami perpaduan dengan gaya pendidikan yang diperkenalkan sebelum Islam masuk terutama pada model pendidikan dan pengajaran yang diperkenalkan oleh masyarakat Hindu maupun tradisional Indonesia, yang pada akhirnya saat ini menjadikan pesantren sebagai sebuah sorotan sekaligus simbol pendidikan Islam di Indonesia.

Berdasarkan pendidikan yang diselenggarakan, pesantren dapat dibagi menjadi dua jenis, yaitu 'pesantren tradisional' dan 'pesantren modern'. Pesantren tradisional tidak mengajarkan ilmu-ilmu umum, melainkan ilmuilmu agama (Islam) saja. Selain itu, pesantren tradisional tidak menggunakan sistem pembagian kelas maupun absensi terhadap mereka yang hendak belajar agama (non-klasikal). Berbeda halnya dengan pesantren modern yang mengajarkan perpaduan antara ilmu-ilmu agama dengan ilmu-ilmu umum. Pesantren modern mengajarkan ilmu-ilmu umum yang biasanya dilaksanakan di sekolah-sekolah sekuler, meskipun demikian, pesantren modern tetap mengajarkan kitab-kitab Islam klasik yang telah menjadi tradisi. Maka dari itu pendidikan di pesantren modern merupakan perpaduan antara model pendidikan pesantren dan sekolah sekuler (klasikal). Ziemek (dalam Zarkasyi) menyatakan bahwa "pesantren pada akhir abad ke-20 mempunyai beberapa jenis. Jenis pertama adalah pesantren yang menggunakan masjid sebagai tempat pengajaran. Jenis ini khas untuk kaum sufi (pesantren-tarekat) yang memberikan pengajaran bagi anggota tarekat. Jenis kedua adalah pesantren yang sudah dilengkapi dengan pondokan dari kayu atau bambu yang terpisah dari kyai. Jenis ketiga adalah pesantren jenis kedua yang dikembangkan dengan pendirian madrasah yang memberikan pelajaran umum dan berorientasi pada sekolah-sekolah pemerintah. Jenis pesantren keempat lebih maju lagi dari jenis ketiga karena dilengkapi dengan program tambahan (ekstrakurikuler). Jenis pesantren kelima adalah pesantren yang memiliki komponen pesantren klasik yang dilengkapi dengan sekolah formal mulai tingkat SD sampai dengan universitas."7 Hal ini juga semakin di perkuat dengan pendapat Daulay yang menjelaskan pendidikan Islam pada masa pembaruan: "Pesantren dilengkapi dengan sekolah umum. Sekolah umum yang ada di pesantren materi pelajaran umum seluruhnya berpedoman kepada kurikulum Departemen Pendidikan Nasional. Sedangkan materi pelajaran agama disusun oleh pengasuh pesantren sendiri. Di luar kurikulum pendidikan

\footnotetext{
${ }^{6}$ Bruinessen, van Martin. Kitab Kuning, Pesantren dan Tarekat. Yogyakarta: Gading Publisihing, 2015. h.90

${ }^{7}$ Zarkasyi, Syukri Abdullah.Gontor dan Pembaharuan Pendidikan Pesantren. Jakarta: Raja Grafindo Persada, 2005. h.66-67
} 
agama yang diajarkan di sekolah, pada waktu-waktu yang sudah terjadwal santri menerima pendidikan agama lewat membaca kitab kitab klasik" ${ }^{8}$

Di Medan berdiri Pesantren Ar-Raudlatul Hasanah, pesantren ini berdiri sejak tahun 1982 dan masih aktif hingga saat ini. Pesantren Ar-Raudlatul Hasanah adalah salah satu contoh dari pesantren yang telah mengalami proses pembaruan didalam menjalankan pendidikannya, dengan mengadopsi kurikulum Kulliyatul Mu'alimin Al-Islamiyah (KMI) yang berasal dari Pesantren Modern Gontor dan kurikulum nasional milik pemerintah. Sejarah mengenai berdirinya pesantren Ar-Raudlatul Hasanah tidak terlepas dengan kegiatan yang dilakukan masyarakat Paya Bundung. Pada saat itu, masyarakat Paya Bundung mengenal budaya pengajian, yang membahas mengenai masalahmasalah keislaman dan pembacaan yasin mingguan. Pada 15 Januari 1981, saat acara peringatan maulid Nabi Muhammad SAW bertepatan dengan acara syukuran masuk rumah baru di kediaman Drs. M. Ilyas Tarigan, Ust. Usman Husni diundang untuk memberikan tausyiah yang di antara isinya adalah menyinggung tentang keluarga yang telah mapan secara ekonomi dan intelektual, tetapi belum mapan secara pendidikan agama, hal ini disebabkan karena keluarga tersebut belum ada yang menempuh pendidikan dalam bidang agama. Padahal sudah banyak pengajian diadakan, bahkan banyak di antara anggota keluarga ini yang berjihad untuk menghidupkan dakwah, mengingat masih banyak keluarga yang belum memeluk agama Islam. Di satu sisi, mereka juga harus memikirkan estafet perjuangan yang salah satu cara mempersiapkannya adalah melalui jalur pendidikan.

Masyarakat Paya Bundung dan sekitarnya yang sejak lama berkeinginan mendirikan lembaga pendidikan agama pun menyambut dengan antusias. Isi tausyiah di atas seakan menjadi dorongan untuk segera mewujudkan lembaga yang dimaksud, sebagaimana yang sudah sering mereka gagas sejak lama. Di sela-sela pengajian khusus yang selalu diadakan di rumah H.M. Mochtar Tarigan, hal ini selalu didiskusikan. Pembahasan dalam pengajian-pengajian inilah yang menjadi embrio kelahiran 'pesantren'. Dari komunikasi dan interaksi intensif di atas, dan setelah mengkaji model dan bentuk lembaga pendidikan yang diinginkan, maka disepakati untuk mendirikan lembaga pendidikan Islam berbentuk pesantren. Dalam Profil Ar-Raudlatul Hasanah disebutkan bahwa "sebuah pengajian tafsir dirumah H.M. Mochtar Tarigan, saat pembahasan ayat 32 dari surah an-Naba', pada jilid pertama halaman 16 di dalam tafsir Al-Shawy disebutkan bahwa maksud dari 'hadaiq' dalam ayat tersebut adalah 'Ar-Raudlatul Hasanah' (taman surga yang indah). Pada saat itu tercetuslah ide untuk menamai pesantren ini dengan 'Ar-Raudlatul Hasanah' dengan harapan bahwa pesantren wakaf tersebut menjadi taman yang indah bagi para pewakil dan pelajarnya dan bagi semua yang berjihad di dalamnya. Setelah dibahas, masyarakat pun menyetujui nama tersebut. Setelah melalui

${ }^{8}$ Daulay, Putra Haidar. Sejarah Pertumbuhan dan Pembaharuan Pendidikan Islam Di Indonesia. Jakarta: Kencana Prana Media Group, 2009. h.68 
proses yang panjang, pada tanggal 18 Oktober 1982, bertepatan dengan peringatan tahun baru Hijriah 1 Muharram 1403, dideklarasikanlah pendirian Pesantren Tarbiyah Islamiyah Ar-Raudlatul Hasanah secara resmi". ${ }^{9}$

Sejak awal berdirinya pesantren ini pembangunan fisik selalu diadakan secara gotong royong dan suka rela tanpa imbalan antara masyarakat, wali santri dan pengelola pesantren, kesemuanya itu dilakukan dengan model pengelolaan wakaf. Pesantren Ar-Raudlatul Hasanah setiap tahun bertambah luasnya dari awal berdirinya hingga saat ini. Pesantren bercita-cita seperti layaknya Universitas Al-Azhar di Mesir dan beberapa lembaga pendidikan internasional lainnya yang memberikan beasiswa kepada anak didiknya.

\section{Kurikulum Pesantren Ar-Raudlatul Hasanah}

Kurikulum pada dunia pendidikan memiliki berbagai macam definisi, kurikulum yang dikenal tidak hanya dimiliki oleh lembaga-lembaga pendidikan yang dinaungi oleh pemerintahan, jauh sebelum Indonesia merdeka pendidikan Islam seperti halnya pesantren, sekolah dan madrasah dikelola oleh badan atau organisasi keagamaan maupun perorangan, dan lembaga pendidikan tersebut telah memiliki kurikulum sebagai wujud keberlangsungan pada pendidikannya salah satunya yaitu pesantren.

Kurikulum berasal dari bahasa Latin, yakni curriculum yang artinya a running course atau race course, especially a chariot race course. Juga diambil dalam bahasa Perancis, yakni courier artinya berlari (to run). Istilah kurikulum berkembang dan dirumuskan dengan berbagai arti. Secara tradisional, kurikulum diartikan sebagai mata pelajaran yang diajarkan di sekolah. ${ }^{10}$ Dengan demikian kurikulum juga dapat diartikan sebagai perencanaan pendidikan yang berisi kegiatan berupa program yang harus dicapai oleh peserta didik, di mana di dalam komponen kurikulum terdapat anak didik atau siswa-siswi dan guru.

Kurikulum dalam lembaga pesantren memiliki beberapa jenis, di antaranya ada yang menetapkan sendiri kurikulumnya dan ada juga yang mengadopsi kurikulum nasional terutama pada lembaga pendidikan terpadu dengan madrasah. Kurikulum yang dimiliki oleh Pesantren Ar-Raudlatul Hasanah dikenal dengan nama Kuliiyatul Mu'allimin Al-Islamiyah atau disingkat dengan nama KMI. KMI Ar-Raudlatul Hasanah merupakan pengadopsian dari Pesantren Modern Gontor. Pengadopsian ini dilakukan, dikarenakan Ustadz Usman Husni merupakan kyai yang pertama kali melaksanakan pengajaran di pesantren merupakan alumni Gontor, sehingga apa yang kyai dapatkan selama menempuh pendidikan pada Pesantren Gontor beliau bawa untuk pelaksanaan pendidikan di Pesantren Ar-Raudlatul Hasanah. Mengenai asal mula KMI, Zarkasyi (2005:114) menjelaskan bahwa "pada awal dekade ketiga abad ke-20, di Mingkabau telah berdiri sistem pendidikan modern salah satunya Noormal Islam

\footnotetext{
${ }^{9}$ Profil Pesantren Ar-Raudlatul Hasanah 2009. h.5

10 Saebani, Basri.Ilmu Pendidikan Islam (Jilid II). Bandung: CV Pustaka Setia, 2010. h.176
} 
(Kulliyat al-Mu'allimin al-Islamiyah). ${ }^{11}$ Zarkasyi salah seorang pendiri Gontor dan penggagas berdirinya Kulliyat al-Mu'allimin al-Islamiyyah di Gontor telah belajar di Noormal Islam, sehingga dapat disimpulkan bahwasanya kurikulum ini awalnya dipopulerkan oleh sekolah Noormal Islam di Minangkabau.

Kurikulum KMI yang dipakai pada lembaga Pesantren Ar-Raudlatul Hasanah tidak jauh berbeda dengan apa yang dimiliki oleh Pesantren Gontor. Ada dua jenjang pendidikan yang diselenggarakan oleh Gontor, yaitu jenjang menengah dengan nama Kulliyatul al-Mu'allimin al-Islamiyah." Jenjang pendidikan menengah yang dimaksud adalah Madrasah Tsanawiyah dan Madrasah Aliyah. Begitu pula dengan pesantren Ar-Raudlatul Hasanah proses pendidikan berlangsung selama 24 jam, semua kegiatan dari para santri sudah di jadwalkan dengan baik. Pelajaran agama dan umum yang diberikan dalam jangka waktu 6 tahun lamanya. Pendidikan keterampilan, kesenian, olahraga, organisasi dan lain-lain merupakan bagian dari kegiatan kehidupan santri di pesantren."12 Program-program dalam kurikulum KMI ini diperuntukkan kepada tingkat Madrasah Tsanawiyah dan Madrasah Aliyah, yang dibuka pada tahun 1989 dan 1990.

KMI merupakan poros bagi jalannya pendidikan dan pengajaran tingkat menengah di Pesantren Ar-Raudlatul Hasanah, karena sejak didirikan pesantren telah menggunakan kurikulum KMI pada pendidikannya secara penuh. Ustadz Carles Ginting dan Ustadz Erwin menjelaskan bahwa:

\begin{abstract}
"KMI merupakan sistem pendidikan yang mengajarkan seorang anak untuk menjadi guru, dalam Kulliyatul Mu'allimin al-Islamiyah, terdapat kata Mu'allimin yang berarti guru, karena dalam konsep kami pada pesantren, semua memang harus jadi guru tapi bukan berarti dia menjadi guru yang dalam artian sempit harus mengajar di kelas, melainkan kami harus bisa menanamkan kepada mereka para santri-santri di pesantren untuk memiliki jiwa mendidik, terlepas dari apapun kelak profesinya, mau dia angkatan, bisnisman, pemerintahan atau yang lain sebagainya dia harus sadar bahwa mendidik itu memang menjadi suatu kewajiban kita, kalau tidak bisa mendidik orang lain, ya minimal keluarga." 13

"Anak-anak bukan hanya diberikan proses pembelajaran tentang ilmu pengetahuan tetapi juga ilmu tentang karakter mereka, pendidikan mereka seharihari juga di didik. Dan di samping itu semua sebelum mereka lulus dari pesantren nantinya mereka harus memiliki kesadaran serta diharapkan mampu menjadi seorang guru baik itu di sekolah, keluarga, masyarakat dan lain sebagainya, dalam artian bahwasanya Kuliiyatul Mu'allimin Al-Islamiyah mampu melahirkan generasi yang mengerti tentang keguruan." 14
\end{abstract}

Sebagaimana yang telah dikemukakan di atas bahwa model pendidikan seperti KMI merupakan kurikulum pendidikan yang dijalankan selama 6 tahun dan diharapkan melahirkan generasi yang mampu mendidik masyarakat

\footnotetext{
${ }^{11}$ Zarkasyi, Syukri Abdullah.Gontor dan Pembaharuan Pendidikan Pesantren. Jakarta: Raja Grafindo Persada, 2005. h.114

12 Zarkasyi, Syukri Abdullah. Manajemen Pesantren Pengalaman Pondok Modern Gontor.

Gontor: Trimurti Press, 2005. h.105

${ }^{13}$ Hasil wawancara dengan Ustadz Carles Ginting tanggal 14 Maret 2017.

${ }^{14}$ Hasil wawancara dengan Ustadz Erwin tanggal 19 April 2017
} 
seminimal mungkin mampu mendidik keluarga sendiri. Dalam proses pembelajarannya dukungan dari kurikulum KMI ini sangat membantu terutama pada proses pembelajaran At-Tarbiyah $W a$ al Ta'lim, yang tidak dimiliki oleh sekolah umum biasanya, para santri akan diberikan pembelajaran micro-teaching (how the teach in the classroom). Para santri akan diajarkan berupa Rencana Proses Pembelajaran (RPP) yang sederhana. Program yang dijalankan selama mereka mendapatkan pendidikan di pesantren Ar-Raudlatul Hasanah, akan mendorong mereka menjadi seorang guru yang menjadi profesi mayoritas para alumninya.

Mitra edisi 25 menjelaskan bahwa: "Pesantren Ar-Raudlatul Hasanah adalah pesantren yang menggunakan kurikulum Kuliiyatul Mu'allimin AlIslamiyah, yang dapat dimaknai sebagai lembaga persamaian guru-guru Islami. Oleh karena itu setiap tahun diadakan micro-teaching atau amaliyah tadris bagi santri-santriwati kelas VI KMI."15 Isi kurikulum ini sama halnya dengan yang dimiliki oleh Pesantren Modern Gontor. Zarkasyi menjelaskan bahwa "KMI dibagi menjadi delapan bagian dan salah satu di antaranya ilmu keguruan, alTarbiyah wa al-Ta'lim (pendidikan dan pengajaran) dan psikologi pendidikan."16

Walaupun demikian, bukan berarti lulusan yang tidak menjadi tenaga pendidik merupakan kegagalan dari sistem KMI. Seperti yang dijelaskan sebelumnya bahwa tidak semua lulusan memiliki profesi yang sama. Ustadz Carles Ginting menjelaskan bahwa:

\footnotetext{
“Di Jakarta ada seorang pengusaha besi yang merupakan alumni dari Pesantren, ketika dia menjadi seorang pengusaha, bukan berarti dia meninggalkan semuanya yang pernah ia dapatkan di pesantren, setiap hubungan yang berkaitan dengan keagamaan tentunya merupakan hal yang nomor satu untuk dilaksanakan, sehingga dia akan mendidik keluarganya dan tetap menjalankan semuanya ketika dia menjadi seorang pebisnis agama bukan berarti menjadi hal yang nomor dua untuknya." 17
}

Proses pembelajaran yang nantinya disampaikan akan membekas pada diri santri walaupun kelak mereka menjadi alumni Pesantren Ar-Raudlatul Hasanah. Pesan-pesan yang selalu disampaikan dalam materi pembelajaran. Kurikulum ini dapat menumbuhkan jiwa para santri, agar mereka kelak memiliki pemikiran yang kritis, terbuka, dan komparatif. Namun model pendidikan KMI ini tidaklah akan berjalan jika tidak ada guru yang mampu dan berkompeten di dalamnya. Pesantren Ar-Raudlatul Hasanah hanya menerima guru yang telah lolos seleksi ketat, baik darimana asal universitas serta pengalaman mereka di dunia pendidikan pesantren.

Guru-guru tersebut harus mampu memberikan penyajian serta langkahlangkah yang ditempuh dalam proses pembelajaran KMI. Ada berapa langkah yang dijadikan pedoman dalam penyajian materi ajar KMI. Seperti, pada

\footnotetext{
${ }^{15}$ Mitra Edisi 25. Media Informasi Tahunan Ar-Raudlatul Hasanah. Medan, 2015. h.7

${ }^{16}$ Zarkasyi, Syukri Abdullah. Manajemen Pesantren Pengalaman Pondok Modern Gontor. Gontor: Trimurti Press, 2005. h.146

${ }^{17}$ Hasil wawancara dengan Ustadz Carles Ginting tanggal 14 Maret 2017
} 
makna kosa kata yang sulit bagi siswa, guru hendaknya menerangkan makna kosa kata tersebut dengan tahapan; mengucapkannya, menulisnya kemudian baru menjelaskan maknanya. ${ }^{18}$ Hal ini juga disampaikan oleh Kyai Rasyidin Bina bahwa "gaya pengajaran dan penyajian materi berdasarkan kosa kata dengan cara mengucapkannya, menuliskannya lalu menjelaskan mengenai makna dari kata-kata yang diajarkan. ${ }^{19}$ Kegiatan pendidikan yang tersruktur dengan baik ini adalah sebagai bukti bahwasannya kurikulum KMI pada Pesantren Ar-Raudlatul Hasanah telah memiliki pemantapan dan bukti dalam kemajuan pendidikan Islam.

\section{Ar-Raudlatul Hasanah sebagai Pesantren, Madrasah, dan Sekolah}

Pesantren mengemban beberapa peran, utamanya sebagai lembaga pendidikan. Jika ada lembaga pendidikan Islam yang juga sekaligus memainkan peran sebagai lembaga bimbingan keagamaan, keilmuan, kepelatihan, pengembangan masyarakat, dan sekaligus menjadi simpul budaya, maka itulah pondok pesantren. ${ }^{20}$ Pernyataan demikian adalah bukti sebagai penguatan bahwa pesantren merupakan lembaga yang mampu menjalankan aktivitas pendidikannya sesuai kebutuhan masyarakat dewasa ini. Di antara kegiatan yang menjadi ciri khas lembaga pendidikan pesantren adalah spirit (ghirah) mengkaji dan menganalisis karya-karya ulama terdahulu (kutubutturots). Pesantren ArRaudlatul Hasanah sebagai mana ciri pesantren juga melakukan hal yang demikian berupa pengkajian kutubutturots. Ada empat pembahasan besar di dalamnya yaitu, tafsir, hadis, fikih, dan tauhid.

Ar-Raudlatul Hasanah merupakan model pendidikan yang tergolong demikian, sehingga membuatnya menjadikan corak lembaga pendidikan Islam yang kompleks, di samping menjadi pesantren juga berperan sebagai madrasah dan sekolah. Sejarah mengenai adanya madrasah ataupun sekolah dalam lembaga pesantren tidak terlepas dari pembaharuan yang dialami pesantren di Indonesia. Pembaharuan ke arah modernitas lembaga pendidikan Islam ini berasal dari pengaruh sekolah-sekolah sekuler yang dibangun oleh pemerintah kolonial. Anis (dalam Daulay) menyebutkan bahwa "istilah madrasah berasal dari bahasa Arab yang artinya adalah tempat belajar." 21 Jika kita lihat apa yang ada di Indonesia saat ini, madrasah merupakan tempat belajar yang memiliki kekhususan dalam penambahan ilmu pengetahuan khususnya agama Islam. Sama halnya dengan madrasah, sekolah juga diartikan sebagai tempat belajar, namun di Indonesia istilah sekolah cenderung digunakan untuk lembagalembaga pendidikan umum yang tidak terfokus kepada mata pelajaran agama saja. Pesantren Ar-Raudlatul Hasanah juga berfungsi sebagai sekolah, di mana santri juga dapat memilih jurusan IPA dan IPS. Para santri yang menyelesaikan

${ }^{18}$ Zarkasyi, Syukri Abdullah. Manajemen Pesantren Pengalaman Pondok Modern Gontor.

Gontor: Trimurti Press, 2005. h.152

${ }^{19}$ Hasil wawancara dengan Kyai Rasyidin tanggal 19 Maret 2017

${ }^{20}$ Muhaimin, Abdul, dkk. Praksis Pembelajaran Pesantren. Yogyakarta: Instite For Training And Development (ITD) Amherst (MA), 2007. h.11

${ }^{21}$ Daulay, Putra Haidar. Sejarah Pertumbuhan dan Pembaharuan Pendidikan Islam Di Indonesia. Jakarta: Kencana Prana Media Group, 2009. h.94 
studinya selama 6 tahun, dari Madrasah Tsanawiyah hingga Aliyah akan diberi tiga bukti tanda kelulusan, atau biasa disebut dengan ijazah. Mereka akan mendapatkan: ijazah dari hasil Ujian Nasional, Ujian Madrasah, dan ijazah kelulusan dari pesantren.

\section{PENUTUP}

Pendidikan pesantren tentunya berbeda dengan lembaga pendidikan umum. Kekayaan kultural yang dimiliki pesantren merupakan modal untuk melaksanakan pendidikan karakter. Di dalamnya terdapat para santri yang berasal dari berbagai macam suku, daerah yang mampu beradaptasi di lingkungan pesantren, baik antar sesama santri, kyai, ustadz dan ustadzah ataupun setiap hal yang termasuk elemen masyarakat pesantren. Pendidikan karakter dimaknai sebagai pendidikan yang mampu mengembangkan nilai-nilai karakter pada diri seseorang, pendidikan karakter akan melahirkan generasi yang berkualitas yang mampu untuk hidup mandiri, peduli antar sesama, toleransi, religius, serta melaksanakan kehidupan sesuai dengan nilai moral dan etika.

Sebagai lembaga pendidikan, pesantren tidak hanya mendidik para santri untuk mempelajari ilmu agama saja, melainkan juga membekalinya dengan akhlak yang menjadi karakter khas dari seorang santri, sehingga tidak salah jika menganggap bahwa pesantren dapat pula disebut sebagai lembaga pendidikan Islam yang membangun karakter. Tidak terlepas dari Pesantren Ar-Raudlatul Hasanah, lembaga pendidikan Islam ini juga salah satu pesantren yang membangun karakter. Hal ini ditunjukkan dari panca jiwa yang dimiliki oleh pesantren, seluruh kehidupan pada Pesantren Ar-Raudlatul Hasanah didasarkan pada nilai-nilai yang dijiwai.

Pertama, jiwa keikhlasan yang berarti melaksanakan sesuatu tanpa pamrih atau berbuat sesuatu bukan karena didorong oleh keinginan untuk mendapatkan keuntungan tertentu. Segala perbuatan dilakukan dengan niat semata-mata untuk beribadah. Semua elemen pada masyarakat Pesantren Ar-Raudlatul Hasanah hendaknya menanamkan serta melaksanakan keikhlasan ini, maka akan menciptakan suasana kehidupan pesantren yang harmonis serta menjadikan seluruh masyarakat pesantren selalu berjuang di jalan Allah, di manapun dan kapanpun.

Kedua, jiwa kesederhanaan, yang muncul dari nilai-nilai kekuatan, kesanggupan, ketabahan dan pengusaan diri dalam menghadapi perjuangan hidup. Di balik kesederhanaan akan terpancar jiwa yang besar, tumbuhnya mental beserta karakter santri juga disebabkan penanaman nilai-nilai kesederhanaan dalam hidup sebagai bentuk perjuangan dalam segala segi kehidupan.

Ketiga, jiwa berdikari, yang berarti menyanggupi menolong diri sendiri merupakan hal yang juga dibekalkan kepada para santri di Pesantren ArRaudlatul Hasanah ini. Berdikari tidak saja berarti bahwa santri sanggup belajar dan berlatih mengurus segala kepentingan sendiri, tetapi sebagai lembaga pendidikan juga harus sanggup berdikari sehingga tidak pernah menyandarkan 
kehidupannya kepada bantuan atau belas kasihan dari pihak-pihak lainnya, sehingga menumbuhkan masyarakat pesantren yang mandiri.

Keempat, jiwa Ukhuwwah Islamiyah sudah menjadi hal yang tidak terlepaskan jika suasana pada pesantren kita temukan suasana persaudaraan yang akrab, sehingga segala suka dan duka dirasakan bersama. Tidak ada dinding yang memisahkan mereka para masyarakat pesantren. Ukhuwwah ini akan tetap terjalin walau kelak mereka tidak lagi berada pada lingkungan pesantren, atau sudah terjun di masyarakat.

Kelima, jiwa bebas, yang berarti bebas dalam berpikir dan berbuat, bebas dalam menentukan masa depan, bebas dalam memilih jalan hidup, dan bahkan bebas dari berbagai pengaruh negatif dari luar. Jiwa bebas pada pesantren ArRaudlatul Hasanah serta merta akan menumbuhkan hal yang bersifat optimis bagi para santrinya untuk menjalankan kehidupan. Walaupun bebas bukan berarti semua yang berkaitan dengan hal negatif juga dilaksanakan, kebebasan itu dalam koridor garis-garis positif, yang tentunya diridhoi oleh Allah SWT. Sehingga jiwa ini diharapkan akan mampu santri bawakan sebagai bekal dalam kehidupannya di masyarakat.

Sehingga dengan demikian, darimana pun asal mereka para santri, yang menjalankan proses pendidikan di Pesantren Ar-Raudlatul Hasanah, dari berbagai macam bentuk watak, serta perilaku, atau seburuk apapun dia, pesantren akan berusaha mendidiknya dan melakukan yang terbaik untuk mampu memberikan pelajaran yang berharga bagi para santri yang menempuh pendidikan pada pesantren ini, agar kelak nantinya para santri dapat melihat jalan kehidupan, pada arah kebaikan.

\section{REFERENSI}

Bruinessen, van Martin. Kitab Kuning, Pesantren dan Tarekat. Yogyakarta: Gading Publisihing, 2015

Daulay, Putra Haidar. Sejarah Pertumbuhan dan Pembaharuan Pendidikan Islam Di Indonesia. Jakarta: Kencana Prana Media Group, 2009.

Dhofier, Zamakhsyari. Tradisi Pesantren. Jakarta Barat: LP3ES, 2011.

Hasan, Basri. Kapita Selekta Pendidikan. Bandung: CV Pustaka Setia, 2012.

Mitra Edisi 25. Media Informasi Tahunan Ar-Raudlatul Hasanah. Medan, 2015.

Muhaimin, Abdul, dkk. Praksis Pembelajaran Pesantren. Yogyakarta: Instite For Training And Development (ITD) Amherst (MA), 2007.

Profil Pesantren Ar-Raudlatul Hasanah 2009.

Saebani, Basri.Ilmu Pendidikan Islam (Jilid II). Bandung: CV Pustaka Setia, 2010.

Steenbrink, Karel A.Pesantren Madrasah Sekolah Pendidikan Islam Dalam Kurun Modern. Jakarta Barat: LP3ES, 1985. 
Susanto. Pemikiran Pendidikan Islam. Jakarta: Amzah, 2010.

Zarkasyi, Syukri Abdullah.Gontor dan Pembaharuan Pendidikan Pesantren. Jakarta: Raja Grafindo Persada, 2005.

Zarkasyi, Syukri Abdullah. Manajemen Pesantren Pengalaman Pondok Modern Gontor. Gontor: Trimurti Press, 2005.

\section{DAFTAR NAMA WAWANCARA:}

Kyai Rasyidin Bina, 19 Maret 2017 (Direktur Pesantren ar-Raudlatul Hasanah);

Charles Ginting, 14 Maret 2017 (Kepala Bidang Pendidikan Pesantren arRaudlatul Hasanah);

Erwin, 19 April 2017 (Kepala Biro Kulliyatul Muallimin al-Islamiyah Pesantren ar-Raudlatul Hasanah). 